\title{
Timing and Concentration of Hydrogen Cyanamide Affect Blueberry Bud Development and Flower Mortality
}

\author{
J.G. Williamson ${ }^{1}$ and B.E. Maust ${ }^{2}$ \\ Department of Horticultural Sciences, University of Florida, Gainesville, \\ FL 32611
}

D.S. NeSmith
Horticulture Department, Georgia Station, Griffin, GA 30223

Additional index words. Dormex ${ }^{\circledR}$, dormancy, Vaccinium corymbosum, Vaccinium ashei, leaf buds, flower buds

\begin{abstract}
The effects of hydrogen cyanamide $\left(\mathrm{H}_{2} \mathrm{CN}_{2}\right)$ sprays on vegetative and reproductive bud growth and development were evaluated for 'Climax' rabbiteye (Vaccinium ashei Reade) and 'Misty' southern highbush blueberry ( $V$. corymbosum $L$. hybrid). 'Climax' plants were sprayed with $0 \%$ or $1 \% \mathrm{H}_{2} \mathrm{CN}_{2}(\mathrm{v} / \mathrm{v})$ at each of several time intervals or flower bud growth stages following either 270 or 600 hours of artificial chilling. 'Misty' plants were sprayed with $0 \%, 1 \%$, or $2 \% \mathrm{H}_{2} \mathrm{CN}_{2}(\mathrm{v} / \mathrm{v})$ immediately after exposure to 0,150 , or 300 hours of artificial chilling. $\mathrm{H}_{2} \mathbf{C N}_{2}$ application to 'Climax' plants at 3 days after forcing (DAF) and at $10 \%$ to $30 \%$ stage 3 flower bud development dramatically accelerated leafing, and only minimal flower bud damage was observed at these application times. For 'Misty', vegetative budbreak was increased and advanced by both $\mathrm{H}_{2} \mathrm{CN}_{2}$ spray concentrations, regardless of pretreatment chilling levels; the number of vegetative budbreaks per plant increased with increased concentration. Timing of anthesis did not appear to be affected by $\mathrm{H}_{2} \mathrm{CN}_{2}$, but fruit maturity was hastened. Increased pretreatment chilling also hastened fruit development. This effect on maturity appears to be due primarily to increased and accelerated vegetative budbreak, which probably increased leaf : fruit ratios. Greater flower bud mortality from $\mathrm{H}_{2} \mathrm{CN}_{2}$ occurred in nonchilled plants than in those chilled for 150 or 300 hours, especially at $2 \% \mathrm{H}_{2} \mathrm{CN}_{2}$. These results indicate that $\mathrm{H}_{2} \mathrm{CN}_{2}$ has potential value in stimulating vegetative bud development, which potentially hastens maturity in blueberries grown under the mild winter conditions of the Southeast. However, spray concentration and timing of application will be critical to successful use of this compound.
\end{abstract}

Both rabbiteye and southern highbush blueberries grown in the lower southeastern United States often experience mild winters with limited chilling hours. Under these conditions, flowering can be erratic, depending on cultivar and chilling requirement (NeSmith and Bridges, 1992). An even greater problem caused by lack of chilling is poor leafing (Lyrene and Williamson, 1997). Leaf buds of most blueberry cultivars have a higher chilling requirement than do flower buds, and, following low to moderate chilling, many blueberry cultivars will flower but have greatly delayed vegetative budbreak and leaf canopy development. Delayed spring foliation can reduce fruit set and size, and delay fruit maturity, all of which are critical to the early-season blueberry crop in the lower southeastern United States (Williamson and Lyrene, 1995). There-

Received for publication 12 July 2000. Accepted for publication 29 Jan. 2001. Florida Agricultural Experiment Station Journal Series no. R-07889. The cost of publishing this paper was defrayed in part by the payment of page charges. Under postal regulations, this paper therefore must be hereby marked advertisement solely to indicate this fact.

${ }^{1}$ To whom reprint requests should be addressed at: P.O. Box 110690, Gainesville, FL 32611-0690.

${ }^{2}$ Former Graduate Assistant fore, accelerating spring foliation of certain blueberry cultivars is needed to improve overall crop production following mild winters.

Dormex $^{\circledR}$ (50\% hydrogen cyanamide) has been tested for several years for increasing budbreak of various fruit crops, especially when chilling is inadequate (Dokoozlian and Williams, 1995; Erez, 1987; Shulman et al., 1986). To date, research on $\mathrm{H}_{2} \mathrm{CN}_{2}$ in blueberry has been limited, although some field trials have increased and accelerated spring foliation and increased fruit size and earliness (Williamson and Krewer, Univ. of Florida and Univ. of Georgia, respectively, unpublished). The objective of this research was to determine the effect of timing and concentration of $\mathrm{H}_{2} \mathrm{CN}_{2}$ applications with respect to accumulated chilling on leaf bud development, flower bud mortality, and fruit growth and development of blueberry.

\section{Materials and Methods}

Expt. 1. This experiment was conducted with 1-year-old, potted 'Climax' rabbiteye blueberry plants in a greenhouse at Griffin, Ga., during 1996 and 1997. 'Climax' has a reported chilling requirement of 400-500 h below $7{ }^{\circ} \mathrm{C}$. Two chilling treatments were established for $270 \mathrm{~h}$ (low chill) and $600 \mathrm{~h}$ (high chill) in a cold room at 5 to $7^{\circ} \mathrm{C}$. Dormant blueberry plants were sequentially placed in the cooler so that all could be removed on the same date. After chilling, all plants were moved to a greenhouse $\left(24^{\circ} \mathrm{C}\right.$ day/ $18^{\circ} \mathrm{C}$ night) under natural daylight for forcing budbreak and for application of $\mathrm{H}_{2} \mathrm{CN}_{2}$ $\left(\right.$ Dormex ${ }^{\circledR}$ ) treatments. $\mathrm{H}_{2} \mathrm{CN}_{2}(1 \%)$ treatments were as follows: 1) control; 2) $\mathrm{H}_{2} \mathrm{CN}_{2}$ applied $1 \mathrm{~d}$ after forcing (DAF); 3) $\mathrm{H}_{2} \mathrm{CN}_{2}$ applied 3 DAF; 4) $\mathrm{H}_{2} \mathrm{CN}_{2}$ applied when $10 \%$ to $30 \%$ of the flower buds were at stage 3 (Spiers, 1978); and 5) $\mathrm{H}_{2} \mathrm{CN}_{2}$ applied when $30 \%$ to $50 \%$ of the flower buds were at stage 3 . There were six single-plant replicates per treatment in a randomized complete-block design. $\mathrm{H}_{2} \mathrm{CN}_{2}$ sprays were applied with $0.25 \%$ (v/v) $\mathrm{X}-77^{\circledR}$ surfactant to the point of drip using a backpack sprayer.

All flower buds on each plant were counted and evaluated for stage of development weekly, and flower bud mortality was noted. Leaf bud development was assessed weekly for $10 \mathrm{veg}$ etative buds per plant. A stem was randomly selected for each plant and a tag designated the position of the leaf buds to be observed. Leaf bud stages were classified according to the scale of NeSmith et al. (1998). Fruit and yield data were not taken since pollination was not possible in the greenhouse. All data were subjected to analysis of variance (ANOVA) and means were separated by least significant difference (LSD) procedures at $P \leq 0.05$.

Expt. 2. Sixty-three, 2-year-old, containergrown 'Misty' southern highbush blueberry plants were grown outdoors on a gravel bed at Gainesville, Fla., during 1996 prior to the initiation of chilling treatments. Three chilling treatments were established by moving twothirds of the plants into a cold room for either 150 or $300 \mathrm{~h}$ of continuous chilling at 5 to $6^{\circ} \mathrm{C}$. The remaining 21 control plants were never placed in the cold room but were moved into the greenhouse prior to accumulating any chilling outside. $\mathrm{H}_{2} \mathrm{CN}_{2}$ was applied to the point of drip with a backpack sprayer at concentrations of $0,10.2$, or $20.4 \mathrm{~g} \cdot \mathrm{L}^{-1}$, hereafter referred to as $0 \%, 1 \%$, and $2 \%$ (v/v) $\mathrm{H}_{2} \mathrm{CN}_{2}$ sprays. A nonionic surfactant at $0.25 \% \mathrm{v} / \mathrm{v}$ was included in each spray treatment. Sprays were applied immediately after plants were removed from the cold room. After treatment, all plants were placed in a greenhouse where the maximum and minimum temperatures ranged from about $30 \pm 2{ }^{\circ} \mathrm{C}$ and $18 \pm 2{ }^{\circ} \mathrm{C}$, respectively. The plants remained in the greenhouse for several weeks after treatment and were later moved permanently outdoors during flowering for cross-pollination and fruit set.

Flower and vegetative budbreak were measured weekly between 8 Jan. and 5 Feb. by counting all buds that had begun to grow on each plant. A final measurement of vegetative budbreak was taken on 15 Mar. At each measurement date, all flower buds were assessed for development using a modification of the developmental scale reported by Spiers (1978) for rabbiteye blueberry. The number of dead flower buds was also determined for each plant. All fruit were harvested at 3- to 4-d 
intervals beginning at first fruit ripening. A randomized complete-block design with seven single-plant replications per treatment was used. Arcsine transformations were performed on percent data, and ANOVA and regression analysis were used to determine treatment effects.

\section{Results and Discussion}

Expt. 1. The control 'Climax' plants had no stage 6 leaf buds at 30 DAF (Table 1). $\mathrm{H}_{2} \mathrm{CN}_{2}$ applications at $1 \mathrm{DAF}, 3 \mathrm{DAF}$, and at $10 \%$ to $30 \%$ stage 3 flower buds increased stage 6 leaf bud numbers at $30 \mathrm{~d}$ after forcing of plants chilled for $270 \mathrm{~h}$. Only the treatment applied 3 DAF increased stage 6 leaf bud numbers at 30 DAF in plants chilled for $600 \mathrm{~h}$. By $60 \mathrm{DAF}$, only $10 \%$ to $12 \%$ of the control leaf buds had progressed to stage 6 of vegetative development. From $22 \%$ to $80 \%$ of the leaf buds on plants treated with $\mathrm{H}_{2} \mathrm{CN}_{2}$ were at stage 6 , depending on the time of application. The greatest vegetative budbreak for both the lowand high-chill plants occurred for $\mathrm{H}_{2} \mathrm{CN}_{2}$ applied when $30 \%$ to $50 \%$ of the flowers were at stage 3 of development. For the low-chill plants, all $\mathrm{H}_{2} \mathrm{CN}_{2}$ treatments applied $3 \mathrm{DAF}$ or later increased percentage of leaf buds at stage 6 or greater. A similar trend was observed for the high-chill plants.

The high degree of stage 6 leaf bud numbers for $\mathrm{H}_{2} \mathrm{CN}_{2}$ treatments applied at $30 \%$ to

Table 1. Percentage of stage- 6 leaf buds 30 and 60 $\mathrm{d}$ after forcing in response to $\mathrm{H}_{2} \mathrm{CN}_{2}$ sprays $(2 \%)$ applied at different times, or stages of development, to greenhouse-grown 'Climax' blueberry following 270 or $600 \mathrm{~h}$ of chilling.

\begin{tabular}{lcc}
\hline & \multicolumn{2}{c}{ Chilling (h below $7^{\circ} \mathrm{C}$ ) } \\
\cline { 2 - 3 } Time of treatment & 270 & 600 \\
\hline & 30 d after forcing \\
Control & $0 \mathrm{~b}^{\mathrm{z}}$ & $0 \mathrm{~b}$ \\
$1 \mathrm{DAF}$ & $25 \mathrm{a}$ & $18 \mathrm{ab}$ \\
$3 \mathrm{DAF}$ & $40 \mathrm{a}$ & $38 \mathrm{a}$ \\
$10 \%$ to 30\% Stage 3y & $37 \mathrm{a}$ & $3 \mathrm{~b}$ \\
$30 \%$ to 50\% Stage 3 & $2 \mathrm{~b}$ & $0 \mathrm{~b}$ \\
& 60 d after forcing \\
Control & $12 \mathrm{~d}$ & $10 \mathrm{c}$ \\
1 DAF & $27 \mathrm{~cd}$ & $22 \mathrm{bc}$ \\
3 DAF & $40 \mathrm{bc}$ & $43 \mathrm{~b}$ \\
$10 \%$ to 30\% Stage 3y & $53 \mathrm{~b}$ & $28 \mathrm{bc}$ \\
$30 \%$ to 50\% Stage 3 & $80 \mathrm{a}$ & $67 \mathrm{a}$ \\
\hline
\end{tabular}

${ }^{2}$ Means separation within columns and forcing time by LSD, $P \leq 0.05$.

${ }^{y}$ Refers to floral development stage.

Table 2. Blueberry flower bud mortality in response to $\mathrm{H}_{2} \mathrm{CN}_{2}$ applications (2\%) at different stages of development.

\begin{tabular}{|c|c|c|}
\hline \multirow[b]{2}{*}{ Time of treatment } & \multicolumn{2}{|c|}{ Chilling (h below $7^{\circ} \mathrm{C}$ ) } \\
\hline & 270 & 600 \\
\hline & \multicolumn{2}{|c|}{ Flower buds killed (\%) } \\
\hline Contro & $0 \mathrm{c}^{\mathrm{z}}$ & $0 \mathrm{c}$ \\
\hline $1 \mathrm{DAF}$ & $0 \mathrm{c}$ & $0 \mathrm{c}$ \\
\hline $3 \mathrm{DAF}$ & $16 \mathrm{~b}$ & $1 \mathrm{c}$ \\
\hline $10 \%$ to $30 \%$ Stage $3^{y}$ & $12 \mathrm{bc}$ & $26 \mathrm{~b}$ \\
\hline $30 \%$ to $50 \%$ Stage 3 & $34 \mathrm{a}$ & $72 \mathrm{a}$ \\
\hline
\end{tabular}

${ }^{\mathrm{z}}$ Means separation within columns by LSD, $P \leq 0.05$. ${ }^{y}$ Refers to floral development stage.
$50 \%$ stage 3 for flower buds was coupled with substantial flower bud mortality (Table 2). Flower bud removal tends to accelerate leafing; thus, the direct "effect" of $\mathrm{H}_{2} \mathrm{CN}_{2}$ on promoting vegetative budbreak was confounded by the injury to flower buds. $\mathrm{H}_{2} \mathrm{CN}_{2}$ application at $3 \mathrm{DAF}$ and at $10 \%$ to $30 \%$ stage 3 flower buds resulted in a dramatic acceleration of leafing with only minimal flower bud damage.

Expt. 2. Vegetative budbreak of 'Misty' was increased and advanced by both $\mathrm{H}_{2} \mathrm{CN}_{2}$ spray concentrations at 5,7 , and 15 weeks after application regardless of pretreatment chilling levels (Table 3 ). However, significant $\mathrm{H}_{2} \mathrm{CN}_{2} \times$ pretreatment chilling interactions were found, so all treatment combinations are

reported. The number of vegetative budbreaks per plant increased with $\mathrm{H}_{2} \mathrm{CN}_{2}$ concentration regardless of pretreatment chilling. For plants receiving pretreatment chilling, vegetative budbreak increased linearly with increased $\mathrm{H}_{2} \mathrm{CN}_{2}$ concentration. For control plants, most vegetative budbreak occurred between weeks 7 and 15 regardless of pretreatment chilling. However, most vegetative budbreak for $\mathrm{H}_{2} \mathrm{CN}_{2}$-treated plants began prior to week 5 . The number of vegetative budbreaks per plant at 5 weeks after treatments were applied ranged from 62 to 81 for the $1 \% \mathrm{H}_{2} \mathrm{CN}_{2}$ treatment vs. 0 to 2 for the control plants. By 15 weeks after treatment, both $\mathrm{H}_{2} \mathrm{CN}_{2}$ treatments dramatically increased the number of vegetative budbreaks per plant. At 5 and 7 weeks after

Table 3. $\mathrm{H}_{2} \mathrm{CN}_{2}$ spray concentration and pretreatment chilling effects on the number of vegetative buds growing per plant 5, 7, and 15 weeks after $\mathrm{H}_{2} \mathrm{CN}_{2}$ application.

\begin{tabular}{|c|c|c|c|c|c|}
\hline \multirow{2}{*}{$\begin{array}{l}\mathrm{H}_{2} \mathrm{CN}_{2} \text { spray concn } \\
(\%)\end{array}$} & \multicolumn{3}{|c|}{ Pretreatment chilling $(\mathrm{h})$} & \multicolumn{2}{|c|}{ Significance } \\
\hline & 0 & 150 & 300 & $\mathrm{~L}$ & $\mathrm{Q}$ \\
\hline \multicolumn{6}{|c|}{------- 5 weeks after treatment -------- } \\
\hline 0 & 0.1 & 0 & 2.0 & $* *$ & $* *$ \\
\hline 1 & 62 & 81 & 69 & NS & NS \\
\hline 2 & 71 & 152 & 180 & $* * *$ & NS \\
\hline \multicolumn{6}{|l|}{ Significance } \\
\hline $\mathrm{L}$ & $* * *$ & * & $* * *$ & & \\
\hline Q & $*$ & NS & NS & & \\
\hline \multicolumn{6}{|c|}{--- 7 weeks after treatment } \\
\hline 0 & 1.4 & 0.7 & 3.0 & NS & * \\
\hline 1 & 68 & 76 & 79 & NS & NS \\
\hline 2 & 94 & 146 & 183 & $* *$ & NS \\
\hline \multicolumn{6}{|l|}{ Significance } \\
\hline $\mathrm{L}$ & $* * *$ & $* * *$ & $* * *$ & & \\
\hline Q & $*$ & NS & NS & & \\
\hline \multicolumn{6}{|c|}{15 weeks after treatment } \\
\hline 0 & 15 & 11 & 23 & NS & NS \\
\hline 1 & 68 & 94 & 72 & NS & NS \\
\hline 2 & 82 & 161 & 178 & $*$ & NS \\
\hline \multicolumn{6}{|l|}{ Significance } \\
\hline $\mathrm{L}$ & $* *$ & $* * *$ & $* * *$ & & \\
\hline Q & NS & NS & NS & & \\
\hline
\end{tabular}

Table 4. $\mathrm{H}_{2} \mathrm{CN}_{2}$ spray concentration and pretreatment chilling effects on the percentage of total fruit harvested by 16, 17, and 18 weeks after treatment application to 'Misty' blueberry.

\begin{tabular}{|c|c|c|c|c|c|}
\hline \multirow{2}{*}{$\begin{array}{l}\mathrm{H}_{2} \mathrm{CN}_{2} \text { spray concn } \\
(\%)\end{array}$} & \multicolumn{3}{|c|}{ Pretreatment chilling $(\mathrm{h})$} & \multicolumn{2}{|c|}{ Significance } \\
\hline & 0 & 150 & 300 & $\mathrm{~L}$ & $\mathrm{Q}$ \\
\hline \multicolumn{6}{|c|}{------ 16 weeks after treatment } \\
\hline 0 & 5.5 & 1.4 & 1.6 & NS & NS \\
\hline 1 & 24 & 31 & 21 & NS & NS \\
\hline 2 & 32 & 33 & 71 & $* * *$ & $* *$ \\
\hline \multicolumn{6}{|l|}{ Significance } \\
\hline $\mathrm{L}$ & $* * *$ & $* * *$ & $* * *$ & & \\
\hline Q & NS & $* * *$ & $*$ & & \\
\hline \multicolumn{6}{|c|}{--- 17 weeks after treatment } \\
\hline 0 & 8.7 & 11 & 21 & $*$ & NS \\
\hline 1 & 33 & 33 & 55 & $* *$ & NS \\
\hline 2 & 40 & 42 & 92 & $* * *$ & **** \\
\hline \multicolumn{6}{|l|}{ Significance } \\
\hline $\mathrm{L}$ & $* * *$ & $* * *$ & $* * *$ & & \\
\hline Q & NS & $* * *$ & NS & & \\
\hline \multicolumn{6}{|c|}{------ 18 weeks after treatment } \\
\hline 0 & 25 & 19 & 47 & * & * \\
\hline 1 & 42 & 44 & 74 & $* * *$ & * \\
\hline 2 & 45 & 49 & 98 & $* * *$ & $* * *$ \\
\hline \multicolumn{6}{|l|}{ Significance } \\
\hline $\mathrm{L}$ & ** & $* * *$ & $* * *$ & & \\
\hline Q & NS & $* * *$ & NS & & \\
\hline
\end{tabular}


treatment, vegetative budbreak increased as pretreatment chilling increased for $0 \%$ and $2 \%$ $\mathrm{H}_{2} \mathrm{CN}_{2}$, but not for $1 \% \mathrm{H}_{2} \mathrm{CN}_{2}$. Moreover, with no pretreatment chilling, the additional increase in vegetative budbreak that occurred from the $2 \% \mathrm{H}_{2} \mathrm{CN}_{2}$ treatment was less than when plants were chilled for 150 or $300 \mathrm{~h}$.

Time of flowering of 'Misty' was not affected by $\mathrm{H}_{2} \mathrm{CN}_{2}$ treatment (data not reported). However, both $\mathrm{H}_{2} \mathrm{CN}_{2}$ treatment and pretreatment chilling advanced fruit development and ripening (Table 4). Significant spray concentration $\times$ pretreatment chilling interactions were noted at most harvest dates for percentage of total fruit harvested, so all treatment combinations are reported. For example, by 16 weeks after treatment, there was no effect of pretreatment chilling on the percentage of total fruit harvested for the $0 \%$ and $1 \% \mathrm{H}_{2} \mathrm{CN}_{2}$ treatments. However, for the $2 \% \mathrm{H}_{2} \mathrm{CN}_{2}$ concentration, the percentage of ripe fruit increased as pretreatment chilling increased. Similarly, at 17 weeks after treatment, there was a greater increase in the percentage of ripe fruit as pretreatment chilling increased from 150 to $300 \mathrm{~h}$ for the $2 \% \mathrm{H}_{2} \mathrm{CN}_{2}$ treatment than for the other treatments. By 17 and 18 weeks after treatment, chilling had resulted in advanced ripening of fruits on both $\mathrm{H}_{2} \mathrm{CN}_{2}$-treated and control plants. Overall, $\mathrm{H}_{2} \mathrm{CN}_{2}$ treatments increased the percentage of ripe fruit on all harvest dates regardless of prechilling treatment. The advanced fruit ripening appeared to be primarily related to the effect of $\mathrm{H}_{2} \mathrm{CN}_{2}$ in stimulating earlier and greater spring leafing. Both vegetative budbreaks per plant and percentage of ripe fruit increased with increasing $\mathrm{H}_{2} \mathrm{CN}_{2}$ concentration, and within each pretreatment chilling level, the $\mathrm{H}_{2} \mathrm{CN}_{2}$ treatments that stimulated the greatest vegetative budbreak also hastened fruit ripening most.

The blueberry fruit development period is known to be inversely related to crop load (Maust et al., 1999). Although leaf : fruit ratios were not measured, the $\mathrm{H}_{2} \mathrm{CN}_{2}$ treatments applied to 'Misty' provided earlier and greater levels of vegetative budbreak, probably resulting in higher leaf : fruit ratios during the major period of fruit development, thus hastening fruit development. However, flower bud mortality and subsequent fruit thinning could also have played a secondary role in influencing fruit maturity date. Flower bud mortality was low for the plants that received some pretreatment chilling prior to treatment with $1 \% \mathrm{H}_{2} \mathrm{CN}_{2}$, which suggests that flower thinning was not a factor in earlier fruit ripening for those treatment combinations (Table 5). However, treatments with $2 \% \mathrm{H}_{2} \mathrm{CN}_{2}$ thinned flower buds and reduced both total fruit number per plant and total fruit fresh weights more than did $1 \%$ $\mathrm{H}_{2} \mathrm{CN}_{2}$ (Table 6). The earlier ripening of fruit at this concentration of $\mathrm{H}_{2} \mathrm{CN}_{2}$ may be partially due to reduced fruit numbers as a result of flower bud thinning.

For plants receiving some pretreatment chilling, there was a compromise between total fruit yield and earliness of fruit ripening following $\mathrm{H}_{2} \mathrm{CN}_{2}$ treatment. Across all pretreatment chilling levels, $1 \% \mathrm{H}_{2} \mathrm{CN}_{2}$ sprays resulted in the greatest fruit number per plant and fruit fresh weight (Table 6). However, fruit ripening was more advanced for the $2 \%$ $\mathrm{H}_{2} \mathrm{CN}_{2}$ treatments for plants receiving 150 or $300 \mathrm{~h}$ of pretreatment chilling. Overall, the effectiveness of $\mathrm{H}_{2} \mathrm{CN}_{2}$ at providing early and high fruit yields of southern highbush blueberry appears to be strongly related to both pretreatment chilling and spray concentration. Both $\mathrm{H}_{2} \mathrm{CN}_{2}$ treatments increased total fruit yield. However, $1 \% \mathrm{H}_{2} \mathrm{CN}_{2}$ increased fruit number and fruit fresh weight per plant more than did the $4 \%$ treatment, where considerable flower bud thinning occurred. Flower bud mortality for both the $1 \%$ and $2 \% \mathrm{H}_{2} \mathrm{CN}_{2}$ concentrations was inversely related to pretreatment chilling, suggesting that some accumulated chilling is needed by plants to minimize flower bud injury from $\mathrm{H}_{2} \mathrm{CN}_{2}$.

Results from these two experiments indicate that $\mathrm{H}_{2} \mathrm{CN}_{2}$ may promote vegetative bud development and hastened fruit development for blueberries grown under the mild winter conditions of the Southeast. However, spray concentration and timing will be critical to its successful use. $\mathrm{H}_{2} \mathrm{CN}_{2}$ applications made before any chilling occurred stimulated less vegetative growth, resulted in higher flower bud mortality, and reduced total yields compared with plants receiving a prechilling treatment. $\mathrm{H}_{2} \mathrm{CN}_{2}$ applied to plants with more than $30 \%$ stage 3 flower buds caused excessive flower bud injury regardless of chilling treatment. Thus, $\mathrm{H}_{2} \mathrm{CN}_{2}$ should not be applied before

Table 5. Effects of $\mathrm{H}_{2} \mathrm{CN}_{2}$ spray concentration and pretreatment chilling on the percentage of flower bud mortality of 'Misty' blueberry.

\begin{tabular}{|c|c|c|c|c|c|}
\hline \multirow{2}{*}{$\begin{array}{l}\mathrm{H}_{2} \mathrm{CN}_{2} \text { spray } \\
\text { concn }(\%)\end{array}$} & \multicolumn{3}{|c|}{$\begin{array}{l}\text { Pretreatment } \\
\text { chilling }\end{array}$} & \multicolumn{2}{|c|}{ Significance } \\
\hline & 0 & 150 & 300 & $\mathrm{~L}$ & $Q$ \\
\hline$\overline{0}$ & 1.0 & 1.5 & 0.1 & NS & NS \\
\hline 1 & 20 & 11 & 2.3 & $* * *$ & NS \\
\hline 2 & 38 & 26 & 19 & $* *$ & NS \\
\hline \multicolumn{6}{|l|}{ Significance } \\
\hline $\mathrm{L}$ & $* * *$ & $* * *$ & $* * *$ & & \\
\hline Q & NS & NS & $* *$ & & \\
\hline
\end{tabular}
0.001 , respectively.

Table 6. Effects of $\mathrm{H}_{2} \mathrm{CN}_{2}$ spray concentration on fruit number and yield of 'Misty' blueberry.

\begin{tabular}{lcc}
\hline \hline $\begin{array}{l}\mathrm{H}_{2} \mathrm{CN}_{2} \text { spray } \\
\text { concn (\%) }\end{array}$ & $\begin{array}{c}\text { Fruit fresh } \\
\text { wt }(\mathrm{g})\end{array}$ & $\begin{array}{r}\text { Total fruit } \\
\text { no./plant }\end{array}$ \\
\hline 0 & 324 & 232 \\
1 & 579 & 345 \\
2 & 465 & 261 \\
Significance & & \\
$\quad$ L & NS & NS \\
$\quad$ Q & $* *$ & $* *$ \\
\hline
\end{tabular}

Ns, ** Nonsignificant or significant at $P \leq 0.01$, respectively. significant chilling has occurred, or at advanced stages of floral development $(>30 \%$ stage 3 buds).

Additional research is needed to determine how to use $\mathrm{H}_{2} \mathrm{CN}_{2}$ properly to improve blueberry leafing and hasten fruit development. Timing under field conditions needs to be assessed, since variability among field plants as to temperature and development is much greater than among greenhouse plants. Cultivar responses need to be compared, and the results need to be correlated with plant development. Timing of $\mathrm{H}_{2} \mathrm{CN}_{2}$ applications will have to be based on plant development rather than calendar date. If application timing is monitored carefully, both high- and low-chill plants can benefit in terms of accelerated leaf development. In most cases, some degree of flower bud injury (25\%) would be acceptable to achieve earlier harvests of higher quality fruit. The benefits of increased and accelerated leafing in terms of earlier fruit maturity, enhanced fruit quality, and greater yield need to be quantified in order to determine the outcome of $\mathrm{H}_{2} \mathrm{CN}_{2}$ applications.

Our data support the idea that $\mathrm{H}_{2} \mathrm{CN}_{2}$ could be used to remove flower buds from young blueberry plants where fruiting is not wanted. Growers often remove flowers by hand, which is both costly and time-consuming. In our study, $\mathrm{H}_{2} \mathrm{CN}_{2}$ applied during advanced stages of flower development caused significant flower bud mortality, but greatly stimulated leaf and shoot growth.

\section{Literature Cited}

Dokoolian, N.K. and L.E. Williams. 1995. Chilling exposure and hydrogen cyanamide interact in breaking dormancy in grape buds. HortScience 30:1244-1247.

Erez, A. 1987. Chemical control of budbreak. HortScience 22:1240-1243.

Lyrene, P.M. and J.G. Williamson. 1997. Highbush blueberry varieties for Florida. Proc. Florida State Hort. Soc. 110:171-174.

Maust, B.E., J.G. Williamson, and R.L. Darnell. 1999. Flower bud density affects vegetative and fruit development in field-grown southern highbush blueberry. HortScience 34:607-610.

NeSmith, D.S. and D.C. Bridges. 1992. Modeling chilling influence on cumulative flowering: A case study using 'Tifblue' rabbiteye blueberry. J. Amer. Soc. Hort. Sci. 117:698-702.

NeSmith, S., G. Krewer, and J.G. Williamson. 1998. A developmental scale for assessing vegetative budbreak in rabbiteye blueberry. HortScience 33:757.

Shulman, Y., G. Nair, and S. Lavee. 1986. Oxidative processes in bud dormancy and the use of hydrogen cyanamide in breaking bud dormancy. Acta Hort. 179:141-148.

Spiers, J.M. 1978. Effect of stage of bud development on cold injury in rabbiteye blueberry. J. Amer. Soc. Hort. Sci. 103:452-455.

Williamson, J.G. and P.M. Lyrene. 1995. Commercial blueberry production in Florida. Univ. Florida Coop. Ext. Serv. Bul. SP-129, Gainesville. 